\title{
Z-11-TETRADECENYL ACETATE: SEX ATTRACTANT OF AGAPETA ZOEGANA (LEPIDOPTERA: TORTRICIDAE), A POTENTIAL SPECIES FOR THE BIOLOGICAL CONTROL OF KNAPWEED
}

\author{
M. ТóTH \\ Research Institute of Plant Protection, Pf. 102, H-1525 Budapest, Hungary \\ P.M. GUERIN and H.-R. BUSER \\ Swiss Federal Research Station for Fruit-Growing, Viticulture and Horticulture, \\ CH-8820 Wädenswil, Switzerland \\ H. MÜLLER \\ Commonwealth Institute of Biological Control, CH-2800 Delémont, Switzerland
}

G. SzÖCS

Research Institute of Plant Protection, Pf. 102, H-1525 Budapest, Hungary

G. SZIRÁKI

Enterprise for Extension in Fruit Growing and Ornamentals, Pf. 108, H-1775

Budapest, Hungary

H. ARN

Swiss Federal Research Station for Fruit-Growing, Viticulture and Horticulture, CH-8820 Wädenswil, Switzerland

In Canada, 78 of the most important weed species are introductions from Eurasia (Frankton and Mulligan 1970). Classical biological control aims to reduce the density of alien weeds below the economic threshold through introduction of specific herbivores from the native distribution area (Peschken 1979). During extended field surveys in central and southeastern Europe, the Commonwealth Institute of Biological Control established the root-mining tortricid Agapeta zoegana Haw. as a promising control agent for Centaurea diffusa Lam. and C. maculosa Lam., 2 important ranch weeds in southwestern Canada (Harris and Myers 1984) and the northwestern United States (Maddox 1982). Due to the limited host range and suitable climatic conditions this moth was chosen for introduction into North America (Müller et al. 1982; Müller 1984). We wish to report an attractant that may be used to monitor the establishment of this beneficial species in its new habitat.

Larvae of A. zoegana were collected from roots of knapweed in western Hungary and eastern Austria, transported to Delémont, and reared on host roots. The sexes were separated at the pupal stage and ca. 20 females and 5 males were sent to Wädenswil where they emerged in a $16 \mathrm{~L}: 8 \mathrm{D}$ cycle at $24^{\circ} \mathrm{C}, 56 \% \mathrm{RH}$, and $3000-6000 \mathrm{~lx}$ in the photophase and $18^{\circ} \mathrm{C}, 85 \% \mathrm{RH}$, and $1 \mathrm{~lx}$ in the scotophase. Extracts of the female sex glands (2-5 days old) were made in the first half of the scotophase. Following anesthesis, the ovipositor tip was everted, removed with forceps, and extracted for some minutes in hexane (ca. $2 \mu \mathrm{L} /$ gland).

Gas chromatography with electroantennographic detection (GC-EAD) (Arn et al. $1975)$ using the male $A$. zoegana antenna as detector $(20 \mathrm{~m}$ Silar $10 \mathrm{c}$ high-resolution gas chromatography column, $2 \mathrm{~min}$ at $40^{\circ} \mathrm{C}, 10^{\circ} \mathrm{C} / \mathrm{min}$ to $60^{\circ} \mathrm{C}$, and $4^{\circ} \mathrm{C} / \mathrm{min}$ to $180^{\circ} \mathrm{C}, \mathrm{EAD} /$ FID split ratio of $1 / 1$ ) provided evidence for a biologically active main component of the extract at the retention time of Z11-14:Ac (for abbreviations, see Table 1). Gas chromatography - mass spectrometry analysis (EI, Finnigan 4015 instrument equipped with a $50 \mathrm{~m} \mathrm{SP} 1000$ column, $3 \mathrm{~min}$ at $50^{\circ} \mathrm{C}, 20^{\circ} \mathrm{C} / \mathrm{min}$ to $100^{\circ} \mathrm{C}$, and $5^{\circ} \mathrm{C} / \mathrm{min}$ to $240^{\circ} \mathrm{C}$ ) confirmed the presence of $Z 11-14:$ Ac as the main component accompanied by a tetradecenyl alcohol at the retention time of $Z 11-14: \mathrm{OH}$ and the $n$-alkane series, heneicosane to nonacosane, with the odd-numbered members predominating. A specific search for acetates 
Table 1. Pheromone-related components found in A. zoegana female sex gland extract

\begin{tabular}{lll}
\hline & & $\begin{array}{c}\text { Amount per } \\
\text { female } \\
\text { (ng) }\end{array}$ \\
\hline Dodecyl acetate & Short form & 0.08 \\
Tetradecyl acetate & $12: \mathrm{Ac}$ & 0.5 \\
$E-11$-Tetradecenyl acetate & $14: \mathrm{Ac}$ & 0.08 \\
$Z-11$-Tetradecenyl acetate & $E 11-14: \mathrm{Ac}$ & 8 \\
$Z-11-$ Tetradecen-1-ol & $Z 11-14: \mathrm{Ac}$ & 1.2 \\
Eicosyl acetate & $Z 11-14: \mathrm{OH}$ & 0.5 \\
Docosyl acetate & $20: \mathrm{Ac}$ & 0.5 \\
\hline
\end{tabular}

$\left(\mathrm{m} / \mathrm{z} 61, \mathrm{CH}_{3} \mathrm{COOH}_{2}{ }^{+}\right)$revealed the presence of lower amounts of an additional tetradecenyl acetate at the retention time of E11-14:Ac, and the saturated acetates dodecyl, tetradecyl, eicosyl, and docosyl (Table 1).

The geometry of the tetradecenyl acetates was confirmed by GC-EAD employing male antennae of Zeiraphera diniana for E11-14:Ac and Pandemis heparana for Z1114:Ac as compound-specific detectors (Guerin et al. 1985).

Field tests were conducted in a knapweed-containing field near Julia Major Experimental Station, Budapest, in 1983, using tetra traps with flaps and rubber caps as dispensers (Arn et al. 1979). Those baited with $211-14$ :Ac ( $\leqslant 0.03 \% \mathrm{E}$ isomer) attracted significant numbers of $A$. zoegana males (Table 2). None of the secondary compounds found in the female gland augmented trap catches when added to the main component; both $Z 11-14: \mathrm{OH}$ and $E 11-14:$ Ac were strongly inhibitory at levels found in the female and above. In an additional test, catches in 4 replicates were 3 with $10 \mu \mathrm{g} \mathrm{Z11-14:Ac,} 7$ with $100 \mu \mathrm{g}$, and 39 with $1000 \mu \mathrm{g}$. Though Z11-14:Ac alone also attracted Agapeta hamana $\mathrm{L}$., treatments containing $Z 11-14: \mathrm{OH}$ at $0.5-2 \%$ or 12 :Ac at $2 \%$ proved superior. As in A. zoegana, E11-14:Ac, 14:Ac, and higher doses of Z11-14:OH were inhibitory.

Table 2. Catches of $A$. zoegana males

\begin{tabular}{|c|c|c|c|c|c|c|}
\hline \multicolumn{5}{|c|}{ Blend composition ( $\mu$ g per cap) } & \multirow{2}{*}{\multicolumn{2}{|c|}{ Total catch* }} \\
\hline \multirow[b]{2}{*}{ 12:Ac } & \multirow[b]{2}{*}{$14: \mathrm{Ac}$} & \multirow{2}{*}{$\begin{array}{c}E 11- \\
14: \mathrm{Ac}\end{array}$} & \multirow{2}{*}{$\begin{array}{l}Z 11- \\
14: A c\end{array}$} & \multirow{2}{*}{$\begin{array}{c}Z 11- \\
14: \mathrm{OH}\end{array}$} & & \\
\hline & & & & & A. zoegana & A. hamana \\
\hline \multicolumn{7}{|c|}{ Test 1.10 replicates, 18 July to August 8} \\
\hline & & & 100 & & $35 \mathrm{a}$ & $9 \mathrm{~b}$ \\
\hline & & 0.5 & 100 & & $2 b$ & $0 \mathrm{~b}$ \\
\hline & & 2 & 100 & & $1 \mathrm{~b}$ & $1 \mathrm{~b}$ \\
\hline & & 10 & 100 & & $0 \mathrm{~b}$ & $0 \mathrm{~b}$ \\
\hline & & & 100 & 2 & 36 a & $23 \mathrm{a}$ \\
\hline & & & 100 & 10 & $2 b$ & $7 \mathrm{~b}$ \\
\hline & & & 100 & 50 & $0 \mathrm{~b}$ & $3 \mathrm{~b}$ \\
\hline & & 2 & 100 & 10 & $6 \mathrm{~b}$ & $0 \mathrm{~b}$ \\
\hline \multicolumn{7}{|c|}{ Test 2.5 replicates, 12 August to 13 September } \\
\hline & & & 100 & & $36 \mathrm{abc}$ & $13 \mathrm{c}$ \\
\hline & & 0.05 & 100 & & $31 a b c$ & $23 \mathrm{c}$ \\
\hline & & & 100 & 0.5 & $55 \mathrm{a}$ & $81 a$ \\
\hline & 10 & & 100 & & $26 \mathrm{bcd}$ & $3 \mathrm{c}$ \\
\hline 2 & & & 100 & & $35 a b c$ & $56 \mathrm{~b}$ \\
\hline 2 & 10 & 0.05 & 100 & 0.5 & $39 a b$ & $69 a$ \\
\hline
\end{tabular}

*Catches followed by the same letter are not significantly different at $P=0.05$ as indicated by $\log (x+1)$ transformation, 2-way analysis of variance, and Duncan's multiple range test. 
In test 2, considerable numbers of Aphelia paleana $\mathrm{Hbn}$. were caught in traps containing Z11-14:Ac with $10 \% E$ isomer, as observed by Booij and Voerman (1984).

211-14:Ac is widespread as a pheromone component in the Tortricidae family, and catches of other species can be expected in monitoring of A. zoegana. Selectivity might be achieved on site with secondary components. Meanwhile, a formulation containing $1000 \mu \mathrm{g} \mathrm{Z11-14:Ac}$ of high isomeric purity appears to be useful for attraction of A. zoegana.

This work was supported by the Swiss National Science Foundation.

Arn, H., S. Rauscher, and A. Schmid. 1979. Sex attractant formulations and traps for the grape moth Eupoecilia ambiguella Hb. Mitt. Schweiz. ent. Ges. 52: 49-55.

Arn, H., E. Städler, and S. Rauscher. 1975. The electroantennographic detector - a sensitive and selective tool in the gas chromatographic analysis of insect pheromones. Z. Naturforsch. 30: 722-725.

Booij, C.J.H., and S. Voerman. 1984. New sex attractants for 35 tortricid and 4 other lepidopterous species, found by systematic field screening in the Netherlands. J. chem. Ecol. 10: 135-144.

Frankton, C., and G.A. Mulligan. 1970. Weeds of Canada. Canada Dept. Agric. Publ. 948.

Guerin, P., H. Arn, and H.R. Buser. 1985. Characterization of some tortricid sex pheromones using the insect antenna as a gas chromatographic detector. pp. 239-250 in Acree, T.E., and D.M. Soderlund (Eds.), Semiochemistry: flavors and pheromones. Walter de Gruyter.

Harris, P., and J.H. Myers. 1984. Centaurea diffusa L. and C. maculosa Lam. diffuse and spotted knapweed (Compositae). Pest status. In Commonwealth Agricultural Bureaux (Ed.), Biological Control Programmes Against Insects and Weeds in Canada 1969-1980. 288 pp.

Maddox, D.M. 1982. Biological control of diffuse knapweed (Centaurea diffusa) and spotted knapweed (C. maculosa). Weed Sci. 30: 76-82.

Müller, H. 1984. Die Strukturanalyse der Wurzelphytophagenkomplexe von Centaurea maculosa Lam. und C. diffusa Lam. (Compositae) in Europa und Interaktionen zwischen wichtigen Phytophagenarten und ihren Wirtspflanzen. Inauguraldissertation der Universität Bern.

Müller, H., D. Schroeder, and A. Gassmann. 1982. Investigations on Agapeta zoegana L. (Lep. Cochylidae), a possible biocontrol agent of spotted knapweed, Centaurea maculosa Lam. (Compositae) in Canada, Final Report, Commonwealth Institute of Biological Control, Delémont.

Peschken, D.P. 1979. Biologische Unkrautbekämpfung in Kanada mit Hilfe von Insekten und Nematoden. $Z$. angew. Ent. 88: 1-16.

(Date received: 198504 25; date revision received: 198506 06; date accepted: 19850606 ) 